\title{
Analisis Kegiatan Pembelajaran Pendidikan Matematika pada masa Pandemic COVID-19 di Negara Asia (Indonesia, Jepang dan Filipina)
}

\author{
Jonathan Simanjuntak ${ }^{1}$, Susi Sihombing ${ }^{2}$, Tuty Novelindah Purba ${ }^{3}$, \\ Agusmanto JB Hutauruk ${ }^{4}$, Simon Panjaitan ${ }^{5}$ \\ 1,2,3, Pascasarjana Universitas HKBP Nommensen Medan \\ ${ }^{4,5}$ Pendidikan Matematika FKIP UHN \\ Jonathansimanjuntak08@gmail.com
}

\begin{abstract}
The purpose of this study was to obtain information about learning activities for mathematics education during the Covid-19 pandemic in Asian countries (Indonesia, Japan and the Philippines). This study used a literature review method. Sampling was carried out using random sampling. In this study, related respondents were Asian countries including Indonesia, Japan and the Philippines. The Covid-19 pandemic has brought significant changes in the world of learning. The differences in these conditions are interesting to study to provide an overview of what is happening in the country and can be used as an evaluation in the future. This study was conducted through literature studies with various sources, both journals and online news. The selected countries are Indonesia, Japan and the Philippines. The selection is done randomly without any background representing the existing continents. Based on the results of the study, it is known the responses, strategies and obstacles that occurred in the education sector during the pandemic. The strategies, successes, and obstacles that occurred in each country were influenced by the readiness of infrastructure and human resources, as well as the initial conditions of the country before the pandemic.
\end{abstract}

Keyword: Pandemic of Covid-19, Mathematics Education in Indonesian, Japan, and Filipina

\begin{abstract}
Abstrak
Tujuan penelitian ini adalah mendapatkan informasi tentang kegiatan pembelajaran pendidikan matematika pada masa pandemic covid-19 di Negara Asia (Indonesia, Jepang dan Filipina). Penelitian ini menggunakan metode kajian literatur, dilakukan penarikan sampel dengan menggunakan Random Sampling. Dalam penelitian ini, responden yang berkaitan yaitu Negara Asia diantaranya Indonesia, Jepang dan Filipina. Pandemi Covid-19 membawa perubahan yang cukup signifikan di dalam dunia pembelajaran. Perbedaan-perbedaan kondisi tersebut menarik untuk dikaji untuk memberikan gambaran umum yang terjadi di negara tersebut dan dapat dijadikan evaluasi kedepannya. Kajian ini dilakukan melalui studi literatur dengan berbagai suber baik jurnal maupun berita secara online. Negara-negara yang dipilih adalah Indonesia, Jepang dan filipina. Pemilihan dilakukan secara acak tanpa latar belakang apapun mewakili benua yang ada. Berdasarkan hasil kajian, diketahui tanggapan, strategi dan hambatan yang terjadi di bidang pendidikan selama pandemi. Strategi, keberhasilan, danhambatan yang terjadi di masing-masing negara dipengaruhi oleh kesiapan sarana prasarana hingga sumber daya manusia, serta kondisi awal negara sebelum pandemi.
\end{abstract}

Kata Kunci: Pandemic Covid-19, Pendidikan Matematika di Indonesia, Jepang, dan Filipina 


\section{Pendahuluan}

Pendidikan merupakan suatu hal penting yang harus diterapkan disetiap negara demi mencipatkan generasi yang baik. Menurut Arifin (2012 : 73) bahwa " Pendidikan merupakan bagian dari kegiatan kehidupan bermasyarakat dan berbangsa”. Sehingga setiap negara tidak akan pernah terlepas dengan dunia pendidikan. Semakin tinggi kualitas pendidikan suatu negara, maka semakin tinggi pula kualitas sumber daya manusia yang dapat memajukan dan mengharumkan negaranya.

Matematika merupakan ilmu universal dalam perkembangan teknologi modern (Suandito, 2017: 13), karena matematika berguna dan banyak memberikan bantuan dalam mempelajari berbagai bidang ilmu yang lain. Perkembangan dunia tidak pernah lepas dari peran penting matematika. Sehingga perkembangan dunia selalu mengacu pada perkembangan matematika. Dengan adanya peran penting matematika pada pendidikan mengharuskan pendidikan matematika diajarkan disetiap kalangan baik tingkat dasar hingga perguruan tinggi.

Kegiatan pembelajaran pendidikan matematika sering dilakukan dengan proses pembelajaran disekolah. Menurut Rizqon (2020: 396) bahwa "Proses pembelajaran di sekolah merupakan alat kebijakan publik terbaik sebagai upaya peningkatan pengetahuan dan skill”. Kegiatan ini juga dianggap dapat meningkatkan interaksi, baik dengan guru maupun antar peserta didik. Dengan kegiatan ini interkasi antara guru dengan peserta didik dapat terjalin dengan baik. Sehingga guru mampu mengetahui perkembangan kemampuan setiap peserta didiknya.

Namun, pada masa saat ini dunia pendidikan tidak dapat dilakukan dengan baik (Rizqon, 2020). Sehingga proses pembelajaran disekolah tidak dapat terapkan. Hal ini disebabkan karena pandemic covid-19, kasus penyebaran pandemic Covid-19 yang mulai terdengar beritanya dari daerah Wuhan, sehingga menjadi awal menyebarnya kekhawatiran seluruh dunia atas penyebaran virus Corona (Hutauruk dan Sidabutar, 2020: 45). Kasus ini menjadi sorotan di berbagai negara khususnya negara Asia. Berbagai dampak yang ditimbulkan pamedic covid-19 termasuk di bidang dunia pendidikan. Menurut UNESCO sekitar 1,3 miliar pelajar dan mahasiswa di seluruh dunia tidak dapat bersekolah atau kuliah sebagaimana biasanya akibat penyebaran COVID-19. Hal ini menjadi sorotan penting bagi pakar pendidikan di seluruh Dunia untuk mencari tindakan sebagai upaya mengatasi penurunan kualitas pendidikan di negaranya masing-masing. Dalam tulisan ini akan dibahas bagaimana kegiatan pembelajaran pendidikan matematika pada masa Pandemic COVID-19 di Negara Asia.

\section{Metode Penelitian}

Metode yang digunakan pada tulisan ini adalah metode kajian literatur. Artikel ini bertujuan untuk mengetahui bagaimana kegiatan pembelajaran pendidikan matematika pada masa pandemic Covid-19 
di Negara Asia. Data ini diperoleh melalui studi literatur antara lain berasal dari penelitian-penelitian terdahulu, buku, dan artikel mengenai kegiatan pembelajaran pendidikan matematika pada masa pandemic covid-19 di negara Asia.

\subsection{Populasi dan Sampel}

Populasi dari penelitian ini adalah negara Asia. Dalam penelitian ini dilakukan penarikan sampel, dengan menggunakan Random Sampling sehingga yang menjadi sampel pada penelitian ini yaitu Negara Indonesia, Jepang dan Filipina.

\section{Hasil dan Pembahasan}

Tindakan yang dilakukan oleh pakar pendidikan atau pemerintahan ketiga negara dalam menangani Covid di bidang pendidikan :

\subsection{Indonesia}

Di Indonesia kasus covid-19 pertama kali di umumkan pada tanggal 03 Maret 2020 setelah diketahui bahwa seorang warga Indonesia terkonfir positif covid (Kompas.com, 2020a). setelah munculnya berita tersebut pemerintah Indonesia dengan singap melakukan tindakan yang preventif dalam mencengah berkembang dan tersebarnya virus tersubut. Salah satu upaya yang dilakukan pemerintah yaitu dengan menerbitkan Surat Edar Nomor 4 Tahun 2020 tentang Pelaksanaan Kebijakan Pendidikan Dalam Masa Darurat Penyebaran Coronavirus Disease (Covid- 19). Pada surat edar tersebut mengumumakan 2 point penting yaitu: 1) Pelaksanaan Ujian Nasional (UN) pada tahun 2020 dibatalkan, 2) Proses Belajar dilaksanakan dari rumah dengan ketentuan bahwa belajar dari rumah melalui daring/ pembalajaran jarak jauh tanpa adanya kontak ataupun pertemuan antara guru dan peserta didik.

Munculnya virus tersebut menimbulkan dampak bagi peserta didik Indonesia. Menurut Kemendikbud (2020) bahwa "Sekitar 6,8 juta pelajar di Indonesia melakukan kegiatan belajar dari rumah". Belajar dari rumah atau Pembelajaran jarak jauh ini akan membuat peserta didik di Indonesia kesulitan konsentrasi dan mengeluh beratnya penungasan soal dari guru, peserta didik jugakan akan merasa jenuh akibat isolasi berkelanjutan berpotensi menimbulkan kecemasan dan depresi bagi peserta didik. Berdasarkan hasil penelitian yang dilakukan Loviana dan Baskara (2020: 68) membuktikan bahwa Covid-19 berdampak negatif pada pembelajaran matematika, pemahaman peserta didik terkait materi dirasa kurang maksimal dan pendidik kurang dapat melakukan penilaian secara komprehensif terhadapt masing-masing peserta didik. Hal yang senada juga diungkapkan oleh wiryanto berdasarkan hasil penelitiannya bahwa adanya pembelajaran daring selama Covid-19 adalah guru dan peserta didik tidak dapat memberi feedback secara cepat, pemahaman anak terhaap suatu materi kurang mendalam, penilaian hanya dilakukan melalui penilaian hasil saja, peserta didik tidak dapat mengumpulkan tugas dengan tepat waktu karena kurangnya alat komunikasi, melonjaknya kebutuhan kuota internet, orang 
tua disibukkan oleh tugas atau pekerjaan anak, dan rasa jenuh pada anak yang merasa hanya berkutat pada tugas, serta tidak jelasnya penjelasan guru ketika pembelajaran melalui aplikasi tatap muka ketika signal buruk sehingga materi yang disampaikan menjadi tidak jelas Pembelajaran matematika pada masa pandemic dilakukan dengan cara lain melalui aplikasi whatsapp, zoom, google classroom (wiryanto, 2020: 131). Hal ini akan menyebabkan kualitas pendidikan di Indonesia akan menurun.

Upaya yang telah dilakukan oleh pemerintah Indonesia dalam mengatasi masalah yang terjadi pada bidang pendidikan yaitu: 1) Untuk meringankan kesulitan pembelajaran di masa Covid-19, kurikulum darurat \& modul pembelajaran dapat digunakan (Kemendikbud, 2020), dan 2) memberikan dukungan dan bantuan berupa kuota internet untuk kepentingan pembelajaran, yang didukung oleh Peraturan Sekertaris Jendral Kementerian Pendidikan dan Kebudayaan No.14 Tahun 2020.

\subsection{Jepang}

Pemerintah Jepang secara resmi mengonfirmasi kasus Covid-19 pertamanya pada 16 Januari 2020 (LIPI, 2020). Setelah mengetahui masalah tersebut pemerintah Jepang dengan sigap mengambil tindakan dengan menerapkan tiga pilar pilar utama sebagai strategi besar untuk mengurangi penyebaran COVID-19 (MHLW, 2020), yaitu: (1) deteksi dini dan respon cepat terhadap klasterklaster penyebaran; (2) optimalisasi fasilitas intensive care terutama bagi mereka yang kondisinya buruk/kritis; dan (3) modifikasi perilaku masyarakat. Pelaksanaan ketiga pilar utama ini berkaitan erat dan saling berimplikasi satu sama lain.

Pada 2 Maret Kementrian Pendidikan, kebudayaan, Olahraga, Ilmu Pengetahuan dan Tekneologi (MEXT) Jepang meminta sekolah diwilayah tersebut untuk ditutup sementara, kemudian MEXT mengumumkan pedoman baru pembukaan sekolah setelah libur musim semi (Kompas, 2020). Berdasarkan sumber data UNICEF bahwa Jepang merupakan salah satu negara yang melaksanakan pembukaan sekolah secara nasional. Pembukaan sekolah di Jepang mewajibkan beberapa peraturan yang harus diterapkan yaitu cek suhu tubuh, buka ventilasi kelas, dilarang mengobrol jarak dekat, pakai masker, meliburkan pihak yang terinfeksi, cuci tangan sebelum makan siang. Sistem pembelajaran yang dilaksanakan yaitu dengan sistem hybrid learning. Aplikasi pembelajaran yang dilakukan yaitu Quiper, Zoom Meet, dan Waseda Moodle. Dalam kegiatan pembelajaran menteri pendidikan Jepang Koichi Hagiuda menyarankan agar sekolah menggunakan checklist mengenai Langkah-langkah melawan infeksi virus yang akan didistribusikan pemerintah (Japanes Times, 2020).

\subsection{Filipina}

Filipina juga merupakan salah satu negara di Asia yang terkena dari persebaran virus corona. Deteksi pertama virus berawal pada 22 Januari 2020, dan berkembang menjadi 633 kasus pada 1 Maret 2020 (Edrada et al., 2020). Berdasarkan kasus-kasus yang ada, pemerintah filipina dan otoritas terkait 
menerapkan langkahlangkah yang hampir serupa dilakukan oleh pemerintah lain. Berdasarkan data UNESCO, sebanyak 28 juta pelajar dari segala tingkatan terimbas dampak dari virus ini di Filipina (Edrada et al., 2020). Usaha pemerintah Filipina sebagai respon terhadap covid diantaranya adalah penerapan command center, peningkatan kapasitas tes, peningkatan infrastruktur kesehatan, dan diberlakukannya aturan-aturan/kebijakan yang mengatur jalannya kehidupan dan pemerintahan dalam masa pandemi (The Asean Post, 2020).

Serangkaian pembatasan yang dilakukan oleh pemerintah FIlipana menyebabkan perlunya dilakukan modifikasi sistem pembelajaran. Maka dari itu, Filipina mengedepankan pembelajaran jarak jauh menggunakan berbagai platform. Komisi Pendidikan Tinggi Filipina (CHED) menyarankan untuk memperkuat pembelajaran online dan blended learning untuk memastikan keberlangsungan pendidikan di Filipina. Metode pembelajaran itu dilakukan salah satunya dengan cara memperkuat tenaga pengajar Filipina dalam menggunakan dan menyiapkan materi dengan berbagai platform yang ada (Tria, 2020).

\subsection{Pembahasan}

Pandemic covid-19 merupakan masalah yang saat ini dihadapi seluruh negara yang ada didunia, hal ini disebabkan karena cepatnya penyebaran virus corana membuat pemerintah disetiap negara kesulitan dalam mengatasi masalah tersebut khusus pemerintah negara di Asia. Berdasarkan uraian pada hasil penelitian, tiga negara yang menjadi pokok bahasan merupakan negara wilayah asia yang terinfeksi virus corana. Munculnya virus corona menimbulkan banyak kendala diberbagai bidang, salah satunya dibidang pendidikan. Sehingga kegiatan belajar mengajar tidak dapat diterapkan dengan baik seperti biasanya.

Pada dasarnya pembelajaran matematika disetiap negara berbeda disesuaikan dengan situasi dan kondisi negara tersebut, demikian juga pada masa pandemik saat ini. kegiatan pembelajaran matematika di tiga negara yang merupakan wilayah negara Asia menerapkan pembelajaran yang berbeda cara ini dilakukan sebagai usaha untuk maju dan belajar dari pengalaman negara lain terus dilakukan agar kualitas sumber daya manusia dapat setara dengan bangsa lain yang telah maju. Tabel.1 menunjukan perbedaan proses pembelajaran di tiga negara tersebut.

Tabel 1. Dampak Covid-19 pada tiga Negara di Asia

\begin{tabular}{|c|c|c|c|c|c|}
\hline Negara & Permasalahan & Kurikulum & $\begin{array}{c}\text { Sistem } \\
\text { Pembelajaran } \\
\end{array}$ & $\begin{array}{c}\text { Aplikasi } \\
\text { Belajar }\end{array}$ & $\begin{array}{c}\text { Upaya } \\
\text { Pemerintah } \\
\end{array}$ \\
\hline Indonesia & $\begin{array}{l}\text { - Pemahaman peserta } \\
\text { didik terkait materi } \\
\text { dirasa } \\
\text { maksimal kurang } \\
\text { - Tidak dapat } \\
\text { mengumpulkan }\end{array}$ & $\begin{array}{l}\text { Mengalami } \\
\text { Perubahan } \\
\text { menjadi } \\
\text { Kurikulum } \\
\text { Darurat } \\
\text { Covid-19 }\end{array}$ & $\begin{array}{l}\text { Daring / } \\
\text { Pembelajaran } \\
\text { Jarak Jauh (PJJ) }\end{array}$ & $\begin{array}{l}\text { whatsapp, } \\
\text { zoom, } \\
\text { google } \\
\text { classroom }\end{array}$ & $\begin{array}{l}1 . \text { Untuk } \\
\text { meringankan } \\
\text { kesulitan } \\
\text { pembelajaran di } \\
\text { masa Covid-19, } \\
\text { kurikulum darurat }\end{array}$ \\
\hline
\end{tabular}




\begin{tabular}{|c|c|c|c|c|c|}
\hline & $\begin{array}{l}\text { tugas dengan tepat } \\
\text { waktu, } \\
\text { - Melonjaknya } \\
\text { kebutuhan } \\
\text { internet, } \\
\text { - Orang tuota } \\
\text { disibukkan oleh } \\
\text { tugas atau pekerjaan } \\
\text { anak, } \\
\text { - Rasa jenuh pada } \\
\text { anak yang merasa } \\
\text { hanya berkutat pada } \\
\text { tugas, serta tidak } \\
\text { jelasnya penjelasan } \\
\text { guru ketika } \\
\text { pembelajaran }\end{array}$ & & & & $\begin{array}{l}\text { \& modul } \\
\text { pembelajaran } \\
\text { dapat digunakan. } \\
\text { 2.Memberikan } \\
\text { dukungan dan } \\
\text { bantuan berupa } \\
\text { kuota internet } \\
\text { untuk kepentingan } \\
\text { pembelajaran }\end{array}$ \\
\hline Jepang & $\begin{array}{l}\text { - Tergangunya } \\
\text { kelender Pendidikan }\end{array}$ & $\begin{array}{l}\text { Tidak } \\
\text { mengalami } \\
\text { perubahan }\end{array}$ & $\begin{array}{l}\text { Hybrid } \\
\text { Learning }\end{array}$ & $\begin{array}{l}\text { Quiper, } \\
\text { Zoom, dan } \\
\text { Waseda } \\
\text { Moodle }\end{array}$ & $\begin{array}{l}\text { 1.Mewajibkan } \\
\text { beberapa } \\
\text { peraturan yang } \\
\text { harus diterapkan } \\
\text { yaitu cek suhu } \\
\text { tubuh, buka } \\
\text { ventilasi kelas, } \\
\text { 2.Dilarang } \\
\text { mengobrol jarak } \\
\text { dekat, pakai } \\
\text { masker, } \\
\text { 3.Meliburkan } \\
\text { pihak yang } \\
\text { terinfeksi, cuci } \\
\text { tangan sebelum } \\
\text { makan siang. }\end{array}$ \\
\hline Filipina & $\begin{array}{l}\text { - Fasilitas tidak } \\
\text { merata di institusi } \\
\text { pendidikan } \\
- \text { Pelatihan yang } \\
\text { tidak merata di } \\
\text { institusi pendidikan - } \\
\text { Permasalahan } \\
\text { teknologi (minim alat } \\
\text { dan jaringan internet) } \\
\text { - Kesulitan adaptasi } \\
\text { - Mengerjakan } \\
\text { pekerjaan rumah } \\
\text { tangga Pa } \\
- \\
\text { finansial keluarga } \\
\text { - Komunikasi minim } \\
\text { antara anak didik dan } \\
\text { pengajar } \\
\text { Ketersediaan listrik } \\
\text { yang tidak merata dan } \\
\text { adanya gangguan } \\
\text { listrik }\end{array}$ & $\begin{array}{l}\text { Tidak } \\
\text { mengalami } \\
\text { perubahan }\end{array}$ & $\begin{array}{l}\text { Pembelajaran } \\
\text { dilakukan } \\
\text { secara daring }\end{array}$ & $\begin{array}{l}\text { Tv } \\
\text { Komunitas, } \\
\text { Radio } \\
\text { Komunitas, } \\
\text { Quiper, dan } \\
\text { Google } \\
\text { Classroom }\end{array}$ & $\begin{array}{l}\text { 1.Menteri } \\
\text { Pendidikan } \\
\text { Briones bersikeras } \\
\text { agar para murid } \\
\text { tetap di rumah, } \\
\text { tetapi belajar } \\
\text { 2.Kementerian } \\
\text { Pendidikan } \\
\text { Filipina menyetop } \\
\text { acara-acara yang } \\
\text { melibatkan murid } \\
\text { dan guru }\end{array}$ \\
\hline
\end{tabular}


Perubahan yang sangat cepat dan mendesak karena adanya pandemic covid-19 mengakibatkan semua negara merespon dengan cepat. Berdasarkan perbedaan tersebut dan kondisi awal masing- masing negara maka dampak yang dirasakan dan tantangan yang dihadapi akan berbeda. Permasalahan permasalahan tersebut dikhususkan dalam tiga negara diantaranya Indonesia, Jepang dan Filipina ditunjukan dalam tabel 1 dimana Indonesia sebagai negara terbesar di Asia Tenggara dengan salah satu negara berpopulasi terbesar didunia memiliki kurang lebih 68 juta peserta didik yang terpengaruh oleh adanya pandemic ini (UNESCO, 2020). Dengan permasalahan yang dialami dimasa pandemic yaitu Pemahaman peserta didik terkait materi dirasa kurang maksimal, tidak dapat mengumpulkan tugas dengan tepat waktu, melonjaknya kebutuhan kuota internet,orang tua disibukkan oleh tugas atau pekerjaan anak, rasa jenuh pada anak yang merasa hanya berkutat pada tugas, serta tidak jelasnya penjelasan guru ketika pembelajaran membuat kurikulum mengalami perubahan dari K13 menjadi kurikulum darurat covid-19, bukan hanya itu sistem pembelajaran yang digunakan yaitu daring atau pembelajaran jarak jauh. Mendukung hal ini maka apilikasi yang digunakan yaitu whatsapp, zoom, dan google classroom. Menanggapi permasalahan yang sedang melanda negara Indonesia maka upaya pemerintah guna menungurangi kendala yang dihadapi diterapkannya kurikulum darurat, memberikan dukungan dan bantuan berupa kuota internet unutk kepentingan pembelajaran.

Berdasarkan sumber data UNICEF bahwa Jepang merupakan salah satu negara yang melaksanakan pembukaan sekolah secara Nasioanal. Akibat permasalahan yang dihadapi diantaranya terganggunya kalender pendidikan membuat sistem pendidikannya yang mengalami gejala Covid-19 dilakukan dengan Daring dan Luring. Sistem ini disebut dengan sistem pembalajaran Hybrid Learning. Sistem pembelajaran ini lakukan dengan menggabungkan pembelajaran online dengan pengajaran di ruang kelas nyata seperti waktu sekolah tatap muka pada umumnya. Apilikasi yang digunakan yaitu Quiper, Zoom dan Waseda Moodle. Upaya Pemerintah membantu permasalahan dalam dunia pendidikan yaitu mewajibkan beberapa peraturan yang harus diterapkan yaitu cek suhu tubuh, buka ventilasi kelas, dilarang mengobrol jarak dekat, pakai masker, meliburkan pihak yang terinfeksi, dan cuci tangan sebelum makan siang.

Kondisi yang serupa terjadi di Filipina dimana terjadi kesenjangan karena masalah ekonomi yang mengakibatkan adanya perbedaan kemampuan adaptasi antara orang berada dan tidak berada terhadap sistem pembelajaran daring. Perbedaan dapat disimpulkan juga dengan indikasi bahwa terdapat kesenjangan yang terjadi tidak hanya di level peserta didik, namun juga dalam institusi pendidikan. Hal tersebut nampak pada tidak meratanya pelatihal perkuliahan daring di institusi pendidikan (Lapada, Miguel, Robledo, \& Alam, 2020). Permasalahan lainnya yaitu pelatihan yang tidak merata di institusi pendidikan, minim teknologi, kesulitan dalam adaptasi, permasalahn finansial keluarga, dan komunikasi minim antara anak didik dan pengajar bahkan ketersediaan listrik yang tidak merata dan adanya gangguan listrik. Sama halnya dengan negara yang dipaparkan sebelumnya bahwa siswtem 
pembelajaran dilakukan secara daring, mendukung hal ini untuk mendapatkan pembelajaran yang maksimal dapat diperoleh dari radio komunitas, tv komunitas, quiper dan google classroom. Pemerintah Filipina juga memberikan bantuan dalam dunia pendidikan dimana Menteri Pendiidkan bersikeras agar para murid tetap dirumah, tetapi belajar bahkan Kementrian Pendidikan Filipina menyetop acara- acara yang melibatkan murid dan guru.

\section{Kesimpulan}

Keberhasilan pembelajaran kala pandemi dipengaruhi oleh kondisi negara sebelum pandemi. Jika kondisi pendidikan sebelum pandemi masih rendah, maka tantangan yang dihadapi kala pandemi makin besar. Kajian ini dilakukan untuk memperoleh gambaran kegiatan pembelajaran pendidikan dan permasalahan yang dialami beberapa negara secara umum diantaranya Indonesia, Jepang dan Filipina. Jumlah negara yang terbatas dalam kajian ini tidak cukup untuk menjadikan hasil kajian ini sebagai suatu generalisasi terhadap suatu kondisi yang lebih luas. Namun, kajian ini memberikan gambaran mengenai beberapa negara yang dikaji. Kedepannya, perlu dilakukan kajian yang lebih komprehensif dengan sampel yang lebih banyak sehingga dapat diketahui secara tepat hubungan atau pengaruh kemajuan suatu negara terhadap dampak dan keberhasilan pembelajaran selama pandemi.

\section{Referensi}

Arifin. A. H. A. (2012). Implimentasi Pendidikan Multikutural dalam Praksis Pendidikan Indonesia. Jurnal Pembangunan Pendidikan: Fondasi dan Aplikasi. 1 (1), 72-82. https://journal.uny.ac.id/index.php/jppfa/article/view/1052/854

Hutauruk, A. \& Sidabutar, R. (2020). Kendala Pembelajaran Daring Selama Masa Pandemi di Kalangan Mahasiswa Pendidikan Matematika: Kajian Kualitatif Deskriptif. SEPREN: Journal of Mathematics Education dan Applied. 2 (1), 45-51.

\section{https://jurnal.uhn.ac.id/index.php/sepren/article/view/364}

Edrada, E. M., Lopez, E. B., Villarama, J. B., Salva Villarama, E. P., Dagoc, B. F., Smith, C., ... Solante, R. M. (2020). First COVID-19 infections in the Philippines: A case report. Tropical Medicine and Health, 48(1). https://doi.org/10.1186/s41182-020-00203- 0

Japanes Times. (2020). Guidelines On Curbing Virus Issued As Japan's Schools Set To Reopen. Retrieved Maret 24, 2020. https://www.japantimes.co.jp/news/2020/03/24/national/japanministry-guidelines-coronavirus-schools/\#.Xuh5m0UzbIW. (Online, diakses 18 Januari 2020)

Kemendikbud. (2020). Surat Edar Mendikbud Nomor 4 Tahun 2020. http://pgdikmen.kemdikbud.go.id/read-news/surat-edaran-mendikbud-nomor-4-tahun-2020 (Online, diakses 18 Januari 2020) 
Kemendikbud. (2020). Penyesuaian Keputusan Bersama Empat Menteri tentang Panduan
Pembelajaran
di
Masa
Pandemi
COVID-19.

https://webcache.googleusercontent.com/search?q=cache:KcDw9N39gG4J:https://www.kem dikbud.go.id/main/blog/2020/08/ (Online, diakses 18 Januari 2020)

Kompas.com. (2020). Fakta Lengkap Kasus Pertama Virus Corona di Indonesia Halaman all -
Kompas.com.
Retrieved
November
19 ,
2020.

https://nasional.kompas.com/read/2020/03/03/06314981/fakta-lengkap-kasus-pertama-viruscorona-di-indonesia?page=all. (Online, diakses 18 Januari 2020)

Kompas.com. (2020). Negara Yang Telah Membuka Sekolah Dimasa Pandemic Corona. Retrieved Agustus 05, 2020. https://www.kompas.com/tren/read/2020/08/05/080000265/daftar-29negara-yang-telah-membuka-sekolah-di-masa-pandemi-corona?page=all. (Online, diakses 18 Januari 2020)

LIPI. (2020). Tiga Pilar Utama Penangan Covid-19 Di Jepang (Edisi Khusus Covid-19, Bagian 4). http://psdr.lipi.go.id/news-and-events/opinions/tiga-pilar-utama-penanganan-covid-19-dijepang-edisi-khusus-covid-19-bagian-4.html (Online, diakses 18 Januari 2020)

Loviana, S. \& Baskara, W. N. (2020). Dampak Pandemic Covid-19 pada Kesiapan pembelajaran Tadris Matematika IAIN Metro Lampung. Epsilon :Jurnal Pendidikan Matematika. 2 (1), 6170. http://jurnal.stkippgribl.ac.id/index.php/epsilon/article/view/625/437

Rizqon, H. S. A. (2020). Dampak Covid-19 pada Pendidikan di Indonesia: Sekolah, Keterampilan, dan Proses Pembelajaran. Salam: Jurnal Sosial dan Budaya Syair-I. 7 (5), 394-404. https://doi.org/10.15408/sjsbs.v7i5.15314

Suanditi, B. 2017. Bukti Informal dan Pembelajaran Matematika. Al-Jabar: Jurnal Pendidikan

Matematika. 8 (1), 13-24. https://doi.org/10.24042/ajpm.v8i1.1160

Tria, J. Z. (2020). The COVID-19 Pandemic through the Lens of Education in the Philippines: The New Normal. International Journal of Pedagogical Development and Lifelong Learning, 1(1), ep2001. https://doi.org/10.30935/ijpdll/8311

Wiryanto. (2020). Proses Pembelajaran Matematika Di Sekolah Dasar Di Tengah Pandemic Covid19. Jurnal Review Pendidikan Dasar : Jurnal Kajian Pendidikan dan Hasil Penelitian. 6 (2). 125-132. https://journal.unesa.ac.id/index.php/PD/article/view/9352 